\title{
Soil Nutrient Uptake and Balance as Influenced by Intercropping and Integrated Nutrient Management
}

\author{
Khumlo Levish Chongloi* \\ KVK Chandel, ICAR-Research Complex for NEH Region, Manipur Centre, Monsangpantha, \\ Chandel District, Manipur, India \\ *Corresponding author
}

\section{Keywords}

Nutrient uptake and balance,

Intercropping

system, Pea-oat, Integrated nutrient management

Article Info

Accepted:

10 January 2021

Available Online:

10 February 2021
The study was conducted at Assam Agricultural University, Jorhat in 2014-15 and 2015-16 to study the nutrient uptake and balance as influence by intercropping and integrated nutrient management in rice fallow. The treatment of the experiment comprised of four main plot treatments of sole crop oat, sole crop pea, different row proportion of oat and pea i.e. 3:2 and 3:3 along with four combinations of nutrient management viz. RDF (inorganics), $50 \% \mathrm{~N}$ of RDF $+50 \% \mathrm{~N}$ through FYM, $50 \% \mathrm{~N}$ of RDF $+50 \% \mathrm{~N}$ through vermicompost and 50\% $\mathrm{N}$ through FYM $+50 \% \mathrm{~N}$ through vermicompost were superimposed on each of the main plots as subplot treatments. The soil nutrients like $\mathrm{N}$, $\mathrm{P}_{2} \mathrm{O}_{5}, \mathrm{~K}_{2} \mathrm{O}$, Zinc and Iron uptake and balance was highest in sole pea culture. Among the intercropping, the highest soil nutrient uptake was recorded in 3:3 row proportion of oatpea intercropping. The data on total gain in nitrogen have revealed that the net soil $\mathrm{N}$ balance of 144.98 and $133.26 \mathrm{~kg} / \mathrm{ha}$ was estimated for 3:2 oat-pea cropping during 201415 and 2015-16, respectively. A loss of $\mathrm{P}$ was calculated due to different cropping system in 2014-15, however during 2015-16 experiment, a positive gain of $1.65 \mathrm{P}_{2} \mathrm{O}_{5} \mathrm{~kg} / \mathrm{ha}$ was observed in 3:3 ratio of oat-pea intercropping. The net gain of available $\mathrm{K}_{2} \mathrm{O}$ was also calculated to be highest in an intercropping of oat-pea at the row proportions of 3:3 in both the years of experimentation. The calculated nutrient uptake by $\mathrm{N}, \mathrm{P}_{2} \mathrm{O}_{5}, \mathrm{~K}_{2} \mathrm{O}, \mathrm{Zn}$ and $\mathrm{Fe}$ was significantly highest in $50 \% \mathrm{~N}$ through vermicompost $+50 \% \mathrm{~N}$ through inorganic fertilizer however nutrient balance of $\mathrm{N}, \mathrm{P}_{2} \mathrm{O}_{5}$ and $\mathrm{K}_{2} \mathrm{O}$ was highest in $50 \% \mathrm{~N}$ through vermicompost $+50 \% \mathrm{~N}$ through FYM in all the years of experimentations. The highest calculated net gain of soil nutrients were also recorded from50\% $\mathrm{N}$ through vermicompost $+50 \% \mathrm{~N}$ through inorganic fertilizer during 2014-15 and 2015-16 respectively.

\section{Introduction}

Intercropping is the agricultural practice of cultivating two or more crops at the same time and space, an old and commonly used cropping practice which aims to match efficiently crop demands to the available growth resources and labour. The most common advantage of intercropping is the production of greater yield on a given piece of land by making more efficient use of the available growth resources using a mixture of 
crops of different rooting ability, canopy structure, height, and nutrient requirements based on the complementary utilization of growth resources by the component crops. Moreover, intercropping improves soil fertility through biological nitrogen fixation with the use of legumes, increases soil conservation through greater ground cover than sole cropping.Intercropping of legume and non-legume forages is the best alternatives which ensures balanced nutrition and palatable fodder (Jeon et al., 1994) to the livestock and also help in fertilizer economy (Oleskho et al., 1995), advantageous in maintenance of soil fertility, efficient land utilization and above all economizing the concentrate feeding.

Nutrient management is an integrated approach that applies ecological knowledge to optimize soil fertility, crop production, ecosystem services, and long-term sustainability. Integrated Nutrient Management refers to the maintenance of soil fertility and of plant nutrient supply at an optimum level for sustaining the desired productivity through optimization of the benefits from all possible sources of organic, inorganic and biological components in an integrated manner. Nitrogen, phosphate, and potash are essential plant nutrients for the production of crops used for food, feed, fibre, and fuel. If over applied, though, nitrogen and phosphate can harm the environment. Efficient use of nutrients can be achieved by the adoption of best nutrient management practices. It include selecting the right fertilizer product and applying the right amount at the right time and place to match plant needs and reduce nutrient losses. In addition, applying manure and adopting a crop production management system to improve soil organic material, reduce pests, control soil moisture, and reduce soil erosion can enhance plant's capability to uptake nutrients. Agriculture remains a soil-based industry, there is no way that required yield increases of the major crops can be attained without ensuring that plants have an adequate and balanced supply of nutrients (Antil and Singh, 2007). The appropriate environment must exist for nutrients to be available to a particular crop in the right form, in the correct absolute and relative amounts, and at the right time for high yields to be realized in the short and long term.

\section{Materials and Methods}

The investigation was carried out in the sandy loam soil of Assam Agricultural University, Jorhat, located at $26^{\circ} 45^{\prime} \mathrm{N}$ latitude and $94^{\circ}$ 12' E longitudes at an elevation of about $87 \mathrm{~m}$ above mean sea level. The soil was medium in organic carbon $(0.52$ and $0.53 \%)$ content, low in available nitrogen (207.50 and 213.47 $\mathrm{kg} / \mathrm{ha}$ ) and medium in available phosphorus (22.52 and $23.12 \mathrm{~kg} / \mathrm{ha}$ ), potassium (145.31 and $148.71 \mathrm{~kg} / \mathrm{ha})$, DTPA-Zn (1.25 and 1.26 $\mathrm{mg} / \mathrm{kg}$ ) and DTPA-Fe (116.33 and 120.51 $\mathrm{mg} / \mathrm{kg}$ ) with acidic ( $\mathrm{pH}$ in 5.2 and 5.4) in reaction. The experiment was laid out in split plot design with three replications for two years. There were four main plot treatments comprising of sole crop oat $\left(\mathrm{C}_{1}\right)$, sole crop pea $\left(\mathrm{C}_{2}\right)$, different row proportion of oat and pea i.e. 3:2 $\left(\mathrm{C}_{3}\right)$ and 3:3 $\left(\mathrm{C}_{4}\right)$ along with four combinations of nutrient management viz. RDF (inorganics) $\left(\mathrm{F}_{1}\right), 50 \% \mathrm{~N}$ of $\mathrm{RDF}+50 \%$ $\mathrm{N}$ through FYM $\left(\mathrm{F}_{2}\right), 50 \% \mathrm{~N}$ of RDF $+50 \%$ $\mathrm{N}$ through vermicompost $\left(\mathrm{F}_{3}\right)$ and $50 \% \mathrm{~N}$ through FYM $+50 \% \mathrm{~N}$ through vermicompost $\left(\mathrm{F}_{4}\right)$ were superimposed on each of the main plots as subplot treatments. The seeds of oat were treated with PSB and pea seeds were treated with PSB and Rhizobium culture @ 100g/kg seeds for all the treatment combinations before sowing of seeds. In calculating balance of nitrogen, the uptake by the crop (s) in sole cropping and intercropping systems and total nitrogen in soil were taken into account. Balance of 
nitrogen in soil was calculated by using the following formulas described by Yadav and Sharma (1980)

Nutrient balance in soil $=\mathrm{Y}-(\mathrm{X}-\mathrm{a})-\mathrm{N}$

Where

$\mathrm{Y}=$ Nutrient removed by the crop

$\mathrm{X}=$ Initial soil status of nutrient elements.

$\mathrm{a}=$ Final status of nutrient elements.

$\mathrm{N}=$ Nutrient added through fertilizer

\section{Results and Discussion}

Effect of intercropping and integrated nutrient management on soil fertility

Soil nitrogen uptake and balance as influenced by intercropping and nutrient management

A perusal of the data (Table 1) reveals that, sole pea enhanced 22.41 and $20.99 \%$ available $\mathrm{N}$ over initial status in 2014-15 and 2015-16 respectively. Increase in available $\mathrm{N}$ by $3: 2$ and 3:3 systems were recorded to be 11.51 and 16.94 percent in 2014-15 and 10.38 and 15.67 percent in 2015-16 over the initial status, respectively. It might be due to the fact that, pea as sole crop or as a component in intercropping systems could have fixed atmospheric nitrogen and thereby contributed towards enrichment in soil nitrogen, a major portion of which was perhaps left out as the residual nitrogen. Significantly the highest $\mathrm{N}$ uptake of 261.81 and $269.93 \mathrm{~kg} / \mathrm{ha}$ was observed in $\mathrm{F}_{3}(50 \% \mathrm{~N}$ through vermicompost $+50 \% \mathrm{~N}$ through inorganic fertilizer) during 2014-15 and 201516 , respectively. The reduction in uptake of $\mathrm{N}$ was 10.29 and 7.61 percent recorded in $\mathrm{F}_{4}(50 \%$ $\mathrm{N}$ through vermicompost $+50 \% \mathrm{~N}$ through FYM) during the two years of experimentations. Increased of nutrients content in the soil is positively affected by fertilizer application (Malhi et al, 2006).
The data on total gain in nitrogen have revealed that the net soil $\mathrm{N}$ balance of 144.98 and $133.26 \mathrm{~kg} / \mathrm{ha}$ was estimated for $3: 2$ oatpea cropping during 2014-15 and 2015-16, respectively. The net gain of available $\mathrm{N}$ was recorded highest in sole pea which is followed by $3: 3$ row proportions in both the years. The calculated net $\mathrm{N}$ balance was highest in $50 \%$ $\mathrm{N}$ through vermicompost $+50 \% \mathrm{~N}$ through FYM in 2014-15 and 2015-16. A decrease of 70.59 and 90.82 percent in 2014-15 and 201516 over application of nutrients through $50 \%$ $\mathrm{N}$ through vermicompost $+50 \% \mathrm{~N}$ through inorganic was noticed due to integrated nutrient management in both the years of experimentation. Application of FYM, vermicompost and green manure alone or in combination with bio-fertilizers supplemented by chemical fertilizers improved the soil fertility (Kumar et.al 2014).

\section{Soil $\mathrm{P}_{2} \mathrm{O}_{5}$ uptake and balance as influenced by intercropping and nutrient management}

Pea in sole culture enhanced the availability of $\mathrm{P}_{2} \mathrm{O}_{5}$ by 42 and 43.72 percent over initial status during 2014-15 and 2015-16, respectively. The increased recorded due to intercropping with oat-pea at the ratio of $3: 2$ and $3: 3$ in 2014-15 was 20.36 and 33.88 percent over the initial status respectively and during 2015-16 it was recorded to be 30.54 and 38.62 percent respectively. Higher content of available nutrients in soil found at the end of vegetative period indicate that pea cultivation does not degrade soil environment (Danilovic and Soltysova, 2010). The final status of soil $\mathrm{P}_{2} \mathrm{O}_{5}$ revealed that the highest ( 33.85 and $35.50 \mathrm{~kg} / \mathrm{ha} \mathrm{P}_{2} \mathrm{O}_{5}$ ) was recorded from $\mathrm{F}_{3}(50 \% \mathrm{~N}$ through vermicompost +50 $\% \mathrm{~N}$ through inorganic fertilizer) which was followed by $\mathrm{F}_{2}(50 \% \mathrm{~N}$ through FYM $+50 \%$ $\mathrm{N}$ through inorganic fertilizer) giving the value of 30.58 and $32.81 \mathrm{P}_{2} \mathrm{O}_{5} \mathrm{~kg} / \mathrm{ha}$ during 2014-15 and 2015-16, respectively. 
Table.1 Nitrogen uptake and balance (kg/ha) as influenced by cropping systems and INM

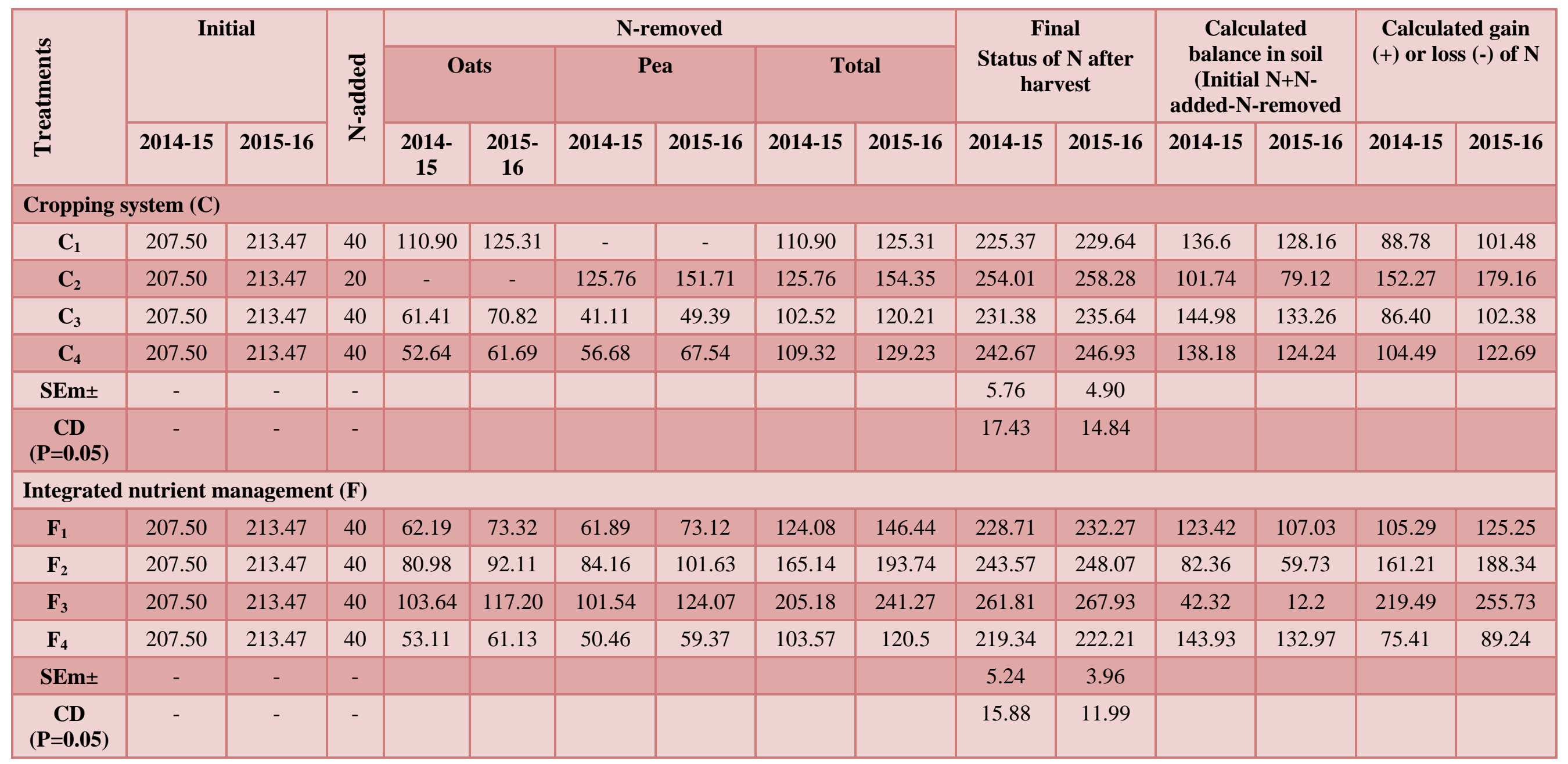


Table.2 Phosphorus uptake and balance (kg/ha) as influenced by cropping systems and INM

\begin{tabular}{|c|c|c|c|c|c|c|c|c|c|c|c|c|c|c|c|}
\hline \multirow[t]{3}{*}{ Treatments } & \multirow{2}{*}{\multicolumn{2}{|c|}{ Initial }} & \multirow{3}{*}{ 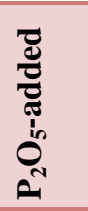 } & \multicolumn{6}{|c|}{$\mathrm{P}_{2} \mathrm{O}_{5}$-removed } & \multirow{2}{*}{\multicolumn{2}{|c|}{$\begin{array}{c}\text { Final } \\
\text { Status of } \mathrm{P}_{2} \mathrm{O}_{5} \\
\text { after harvest }\end{array}$}} & \multirow{2}{*}{\multicolumn{2}{|c|}{$\begin{array}{c}\text { Calculated balance in soil } \\
\text { (Initial } \mathrm{P}+\mathrm{P} \text {-added- } \mathrm{P}_{2} \mathrm{O}_{5^{-}} \\
\text {removed }\end{array}$}} & \multirow{2}{*}{\multicolumn{2}{|c|}{$\begin{array}{c}\text { Calculated gain } \\
(+) \text { or loss (-) of } \\
\mathrm{P}_{2} \mathrm{O}_{5}\end{array}$}} \\
\hline & & & & \multicolumn{2}{|c|}{ Oats } & \multicolumn{2}{|c|}{ Pea } & \multicolumn{2}{|c|}{ Total } & & & & & & \\
\hline & $\begin{array}{c}\text { 2014- } \\
15\end{array}$ & $\begin{array}{c}2015 \\
-16\end{array}$ & & $\begin{array}{c}\text { 2014- } \\
15\end{array}$ & $\begin{array}{c}2015- \\
16\end{array}$ & $\begin{array}{c}2014- \\
15\end{array}$ & $\begin{array}{c}\text { 2015- } \\
16\end{array}$ & $\begin{array}{c}\text { 2014- } \\
15\end{array}$ & $\begin{array}{c}2015- \\
16\end{array}$ & $\begin{array}{c}\text { 2014- } \\
15\end{array}$ & $\begin{array}{c}\text { 2015- } \\
16\end{array}$ & 2014-15 & 2015-16 & $\begin{array}{c}\text { 2014- } \\
15\end{array}$ & $\begin{array}{c}2015- \\
16\end{array}$ \\
\hline \multicolumn{16}{|c|}{ Cropping system (C) } \\
\hline $\mathbf{C}_{1}$ & 22.52 & 23.12 & 20 & 12.42 & 14.21 & - & - & 12.42 & 14.21 & 26.66 & 28.56 & 30.1 & 28.91 & -3.44 & -0.35 \\
\hline $\mathbf{C}_{2}$ & 22.52 & 23.12 & 46 & - & - & 10.31 & 13.11 & 10.31 & 13.11 & 31.98 & 33.23 & 58.21 & 56.01 & -26.23 & -22.78 \\
\hline $\mathbf{C}_{3}$ & 22.52 & 23.12 & 20 & 6.58 & 7.92 & 3.13 & 3.98 & 9.71 & 11.90 & 28.28 & 30.18 & 32.81 & 31.22 & -4.53 & -1.04 \\
\hline $\mathrm{C}_{4}$ & 22.52 & 23.12 & 20 & 5.99 & 6.93 & 4.59 & 5.79 & 10.58 & 12.72 & 30.15 & 32.05 & 31.94 & 30.40 & -1.79 & 1.65 \\
\hline SEm \pm & & & & & & & & & & 0.45 & 0.61 & & & & \\
\hline $\mathrm{CD}(\mathrm{P}=\mathbf{0 . 0 5})$ & & & & & & & & & & 1.36 & 1.86 & & & & \\
\hline \multicolumn{16}{|c|}{ Integrated nutrient management $(F)$} \\
\hline $\mathbf{F}_{1}$ & 22.52 & 23.12 & 20 & 7.04 & 8.51 & 4.70 & 5.68 & 11.74 & 14.19 & 27.19 & 28.62 & 30.78 & 28.93 & -3.59 & -0.31 \\
\hline $\mathbf{F}_{2}$ & 22.52 & 23.12 & 20 & 9.06 & 10.39 & 7.17 & 9.33 & 16.23 & 19.72 & 30.58 & 32.81 & 26.29 & 23.4 & 4.29 & 9.32 \\
\hline $\mathbf{F}_{3}$ & 22.52 & 23.12 & 20 & 11.56 & 13.23 & 8.25 & 10.67 & 19.81 & 23.90 & 33.85 & 35.50 & 22.71 & 19.22 & 11.14 & 16.28 \\
\hline $\mathbf{F}_{4}$ & 22.52 & 23.12 & 20 & 5.68 & 6.63 & 3.92 & 4.82 & 9.60 & 11.45 & 25.45 & 27.10 & 32.92 & 31.67 & -7.47 & -4.57 \\
\hline SEm \pm & & & & & & & & & & 0.48 & 0.44 & & & & \\
\hline $\mathrm{CD}(\mathrm{P}=\mathbf{0 . 0 5})$ & & & & & & & & & & 1.47 & 1.34 & & & & \\
\hline
\end{tabular}


Table. $3 \mathrm{~K}_{2} \mathrm{O}$ uptake and balance $(\mathrm{kg} / \mathrm{ha})$ as influenced by cropping systems and INM

\begin{tabular}{|c|c|c|c|c|c|c|c|c|c|c|c|c|c|c|c|}
\hline \multirow{3}{*}{ Treatments } & \multirow{2}{*}{\multicolumn{2}{|c|}{ Initial }} & \multirow{3}{*}{ 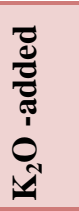 } & \multicolumn{6}{|c|}{$\mathrm{K}_{2} \mathrm{O}$-removed } & \multirow{2}{*}{\multicolumn{2}{|c|}{$\begin{array}{c}\text { Final } \\
\text { Status of } K_{2} O \\
\text { after harvest }\end{array}$}} & \multirow{2}{*}{\multicolumn{2}{|c|}{$\begin{array}{c}\text { Calculated balance in soil } \\
\text { (Initial } \mathrm{K}+\mathrm{K} \text {-added- } \mathrm{K}_{2} \mathrm{O} \text { - } \\
\text { removed }\end{array}$}} & \multirow{2}{*}{\multicolumn{2}{|c|}{$\begin{array}{c}\text { Calculated gain } \\
(+) \text { or loss }(-) \text { of } \\
\mathrm{K}_{2} \mathrm{O}\end{array}$}} \\
\hline & & & & \multicolumn{2}{|c|}{ Oats } & \multicolumn{2}{|c|}{ Pea } & \multicolumn{2}{|c|}{ Total } & & & & & & \\
\hline & $\begin{array}{c}\text { 2014- } \\
15\end{array}$ & $\begin{array}{c}2015- \\
16\end{array}$ & & $\begin{array}{c}\text { 2014- } \\
15\end{array}$ & $\begin{array}{c}\text { 2015- } \\
16\end{array}$ & $\begin{array}{c}\text { 2014- } \\
15\end{array}$ & $\begin{array}{c}\text { 2015- } \\
16\end{array}$ & $\begin{array}{c}\text { 2014- } \\
15\end{array}$ & $\begin{array}{c}\text { 2015- } \\
16\end{array}$ & $\begin{array}{c}\text { 2014- } \\
15\end{array}$ & $\begin{array}{c}\text { 2015- } \\
16\end{array}$ & 2014-15 & 2015-16 & $\begin{array}{c}\text { 2014- } \\
15\end{array}$ & $\begin{array}{c}2015- \\
16\end{array}$ \\
\hline \multicolumn{16}{|c|}{ Cropping system (C) } \\
\hline $\mathbf{C}_{1}$ & 145.31 & 148.71 & 20 & 78.16 & 88.60 & - & - & 78.16 & 88.60 & 164.31 & 166.16 & 87.15 & 80.11 & 77.16 & 86.05 \\
\hline $\mathbf{C}_{2}$ & 145.31 & 148.71 & 20 & - & - & 51.14 & 60.85 & 51.14 & 60.85 & 172.24 & 174.09 & 114.17 & 107.86 & 55.07 & 66.23 \\
\hline $\mathbf{C}_{3}$ & 145.31 & 148.71 & 20 & 42.47 & 49.65 & 16.40 & 19.35 & 58.87 & 69 & 166.61 & 168.92 & 106.44 & 99.71 & 60.17 & 69.21 \\
\hline $\mathrm{C}_{4}$ & 145.31 & 148.71 & 20 & 36.84 & 43.46 & 23.13 & 26.87 & 59.97 & 70.31 & 170.06 & 171.63 & 105.34 & 98.40 & 64.72 & 73.23 \\
\hline SEm \pm & - & - & - & 1.33 & 1.40 & 0.37 & 0.44 & & & 3.39 & 3.26 & & & & \\
\hline $\mathrm{CD}(\mathrm{P}=\mathbf{0 . 0 5})$ & - & - & - & 6.17 & 6.46 & 1.74 & 2.07 & & & NS & NS & & & & \\
\hline \multicolumn{16}{|c|}{ Integrated nutrient management $(F)$} \\
\hline $\mathbf{F}_{1}$ & 145.31 & 148.71 & 20 & 42.57 & 50.35 & 25.05 & 29.02 & 67.62 & 79.37 & 165.64 & 167.57 & 97.69 & 89.34 & 67.95 & 78.23 \\
\hline $\mathbf{F}_{2}$ & 145.31 & 148.71 & 20 & 60.64 & 69.30 & 34.59 & 41.02 & 95.23 & 110.32 & 171.74 & 173.26 & 70.08 & 58.39 & 101.66 & 114.87 \\
\hline $\mathbf{F}_{3}$ & 145.31 & 148.71 & 20 & 69.93 & 80.39 & 39.94 & 48.16 & 109.87 & 128.55 & 177.18 & 179.16 & 55.44 & 40.16 & 121.74 & 139.00 \\
\hline $\mathbf{F}_{4}$ & 145.31 & 148.71 & 20 & 36.81 & 42.24 & 21.31 & 24.54 & 58.12 & 66.76 & 158.67 & 160.80 & 107.19 & 101.95 & 51.48 & 58.85 \\
\hline SEm \pm & - & & - & 1.80 & 1.71 & 1.46 & 1.51 & & & 2.28 & 2.41 & & & & \\
\hline $\mathrm{CD}(\mathrm{P}=\mathbf{0 . 0 5})$ & - & & - & 8.89 & 8.45 & 7.21 & 7.47 & & & 6.92 & 7.31 & & & & \\
\hline
\end{tabular}


Table.4 $\mathrm{Zn}$ and Fe content in the soil as influenced by cropping systems and integrated nutrient management

\begin{tabular}{|c|c|c|c|c|c|c|c|c|}
\hline \multirow{3}{*}{ Treatments } & \multicolumn{4}{|c|}{ Zn-content (mg/kg) } & \multicolumn{4}{|c|}{ Fe-content (mg/kg) } \\
\hline & \multicolumn{2}{|c|}{ 2014-15 } & \multicolumn{2}{|c|}{ 2015-16 } & \multicolumn{2}{|c|}{ 2014-15 } & \multicolumn{2}{|c|}{ 2015-16 } \\
\hline & Initial & $\begin{array}{c}\text { After } \\
\text { harvest }\end{array}$ & Initial & $\begin{array}{c}\text { After } \\
\text { harvest }\end{array}$ & Initial & After harvest & Initial & $\begin{array}{c}\text { After } \\
\text { harvest }\end{array}$ \\
\hline \multicolumn{9}{|c|}{ Cropping system (C) } \\
\hline $\mathbf{C}_{1}$ & 1.25 & 1.45 & 1.26 & 1.46 & 116.33 & 123.56 & 120.51 & 127.58 \\
\hline $\mathbf{C}_{2}$ & 1.25 & 1.64 & 1.26 & 1.66 & 116.33 & 131.93 & 120.51 & 136.42 \\
\hline $\mathbf{C}_{3}$ & 1.25 & 1.50 & 1.26 & 1.52 & 116.33 & 125.69 & 120.51 & 130.81 \\
\hline $\mathrm{C}_{4}$ & 1.25 & 1.58 & 1.26 & 1.60 & 116.33 & 129.28 & 120.51 & 133.71 \\
\hline SEm \pm & - & 0.03 & - & 0.03 & - & 2.69 & - & 3.80 \\
\hline $\mathrm{CD}(\mathrm{P}=0.05)$ & - & 0.10 & - & 0.10 & - & 8.16 & - & 11.51 \\
\hline \multicolumn{9}{|c|}{ Integrated nutrient management (F) } \\
\hline $\mathbf{F}_{1}$ & 1.25 & 1.48 & 1.26 & 1.49 & 116.33 & 123.55 & 120.51 & 130.54 \\
\hline $\mathbf{F}_{2}$ & 1.25 & 1.61 & 1.26 & 1.63 & 116.33 & 132.24 & 120.51 & 135.37 \\
\hline $\mathbf{F}_{3}$ & 1.25 & 1.71 & 1.26 & 1.73 & 116.33 & 137.15 & 120.51 & 141.52 \\
\hline $\mathbf{F}_{4}$ & 1.25 & 1.37 & 1.26 & 1.39 & 116.33 & 117.51 & 120.51 & 121.08 \\
\hline SEm \pm & - & 0.03 & - & 0.05 & - & 3.32 & - & 2.06 \\
\hline $\mathrm{CD}(\mathrm{P}=\mathbf{0 . 0 5})$ & - & 0.11 & - & 0.16 & - & 10.07 & - & 6.24 \\
\hline
\end{tabular}


The data on $\mathrm{P}_{2} \mathrm{O}_{5}$ balance (Table 2) revealed that the highest P-balance was computed in sole pea culture and among the intercropping the highest was recorded from 3:2 row proportions during the years of experiment. A loss of $\mathrm{P}$ was calculated due to different cropping system in 2014-15, however during 2015-16 experiment, a positive gain of $1.65 \mathrm{P}_{2} \mathrm{O}_{5} \mathrm{~kg} / \mathrm{ha}$ was observed in 3:3 ratio of oat-pea intercropping.

Effect of integrated nutrient management on phosphorus balance was observed that the net balance of 32.92 and $31.67 \mathrm{~kg} / \mathrm{ha}$ was noticed in $50 \% \mathrm{~N}$ through vermicompost $+50 \% \mathrm{~N}$ through FYM during 2014-15 and 2015-16 respectively. However the net gain of 11.14 and $16.28 \mathrm{~kg} / \mathrm{ha}$ was observed from50 \% $\mathrm{N}$ through vermicompost $+50 \% \mathrm{~N}$ through inorganic fertilizer during 2014-15 and 2015-16 respectively.

$\mathrm{K}_{2} \mathrm{O}$ uptake and balance in the soil as influenced by intercropping and nutrient management

Cropping system on availability of potassium in the soil was found to be non-significant during the experimental years. However the highest $\mathrm{K}_{2} \mathrm{O}$ in the soil was observed in the sole pea culture recording the highest value of 172.24 and $174.09 \mathrm{~kg} / \mathrm{ha}$ during 2014-15 and 2015-16, respectively. Addition of $50 \% \mathrm{~N}$ through vermicompost $+50 \% \mathrm{~N}$ through inorganic fertilizer recorded the highest $\mathrm{K}_{2} \mathrm{O}$ (177.18 and $179.16 \mathrm{~kg} / \mathrm{ha}$ ) in the soil which was at par with $\mathrm{F}_{2}(50 \% \mathrm{~N}$ through $\mathrm{FYM}+50 \% \mathrm{~N}$ through inorganic fertilizer) giving the value of 171.74 and $173.26 \quad \mathrm{~K}_{2} \mathrm{O} \mathrm{kg} / \mathrm{ha}$ during 2014-15 and 2015-16 respectively (Table 3 ).

The estimation of $\mathrm{K}_{2} \mathrm{O}$ net balance revealed that sole pea crop increased over other cropping in both the years. The highest $\mathrm{K}_{2} \mathrm{O}$ net balance among the intercropping was showed by $3: 2$ row proportions in both the years. The net gain of available $\mathrm{K}$ was calculated to be highest in sole oat but among the intercropping it was observed to be highest in 3:3 row proportions in both the years.
The calculated K-balance as influence by INM was highest in $\mathrm{F}_{4}(100 \%$ organic i.e. $50 \% \mathrm{~N}$ through vermicompost $+50 \% \mathrm{~N}$ through FYM) and the total gain of $\mathrm{K}_{2} \mathrm{O}$ was highest in $\mathrm{F}_{3}$ (50 $\% \mathrm{~N}$ through vermicompost $+50 \% \mathrm{~N}$ through inorganic fertilizers) in both the years of experimentations.

While declined in $\mathrm{K}_{2} \mathrm{O}$ was caused by $100 \%$ organic $(50 \% \mathrm{~N}$ through Vermicompost $+50 \%$ $\mathrm{N}$ through FYM) during 2014-15 and 201516.Application of $50 \%$ recommended dose of fertilizers $(\mathrm{RDF})+50 \% \mathrm{~N}$ through organic showed the highest available N, P and $\mathrm{K}$ of soil of soil after harvest of the crop (Gogoi et al., 2015).

\section{Zinc and Iron content and uptake in the soil}

Zinc content and Zinc uptake in the soil was significantly higher in sole pea culture as compared to other intercropping in both the years. Among the intercropping system the highest zinc content of 1.58 and $1.60 \mathrm{mg} / \mathrm{kg}$ was observed in 3:3 row proportions during 2014-15 and 2015-16, respectively. Similarly the highest Fe-content of 129.28 and $133.71 \mathrm{mg} / \mathrm{kg}$ was recorded in 3:3 row proportions in 2014-15 and 2015-16, respectively (Table 4).

The content and uptake of $\mathrm{Zn}$ and Fe was found to be significantly higher in $50 \% \mathrm{~N}$ through vermicompost $+50 \% \mathrm{~N}$ through inorganic fertilizer.

Application of $50 \% \mathrm{~N}$ through vermicompost with $50 \% \mathrm{~N}$ through RDF increased the Zncontent by 26.90 and 27.17 percent and Fecontent by 15.18 and 14.85 percent over initial soil status during 2014-15 and 2015-16, respectively. The findings are in conformity with Vasanthi and Kumaraswamy (1999).

Addition of organic materials might have enhanced the microbial activity in the soil and consequently the release of complex organic substances like chelating agents could have prevented micronutrients from precipitation, fixation, oxidation and leaching. Application of 
organic nutrients significantly increased availability of micronutrients (Swarup, 1991).

The combined application of various nutrient sources viz., inorganic fertilizer $+50 \% \mathrm{~N}$ through vermicompost along with biofertilizers and $\mathrm{Zn}$ application is beneficial in terms of crop productivity and profitability on garden pea in acidic soil of Eastern Himalaya condition (Kumar, 2014).

From two years study, it can be concluded that, introduction of food-forage intercropping systems having component crop of oat and pea in the rice-fallow with planting geometry of 3:2 row proportion having considerable positive effect on the soil nutrient uptake and balance status. Addition of $50 \% \quad \mathrm{~N}$ through vermicompost $+50 \% \mathrm{~N}$ through inorganic fertilizer can saved $50 \%$ of inorganic fertilizers besides giving best nutrient uptake and balance.

\section{References}

Antil, R.S., Singh, M. Effects of organic manures and fertilizers on organic matter and nutrients status of the soil. Archives of Agronomy and Soil Science. 2007; 53(5): 519-528.

Danilovic, M. and Soltysova, B. (2010). Nutrient management analysis in field pea (Pisum sativa L.) cultivated in the notillage technology. Agriculture (Polnohospodarstvo) 56(1): 18-24.

Gogoi, B., Kalita, B., Deori, B. and Paul, S.K. (2015). Soil properties under rainfed rice (Oryza sativa) crop as affected by integrated supply of nutrients. Intern. J.
Agric. Innov. Res. 3(6).

Jeon, B.T., Lee, S.M., Kim, K.H. and Kim, C.W. (1994). Effects of intercropping methods of sorghum $\mathrm{X}$ Sudan grass hybrid with legumes and $\mathrm{N}$ levels on palatability for ruminants. Korean $J$. Anim. Sci. 36: 323.

Kumar, R., Deka, B.C., Kumawat, N. and Ngachan, S.V. (2014).Effect of integrated nutrition, biofertilizers and zinc application on production potential and profitability of garden pea (Pissum sativum) in Eastern Himalaya, India. Legume Res. 37(6): 614-620.

Malhi, S.S., Lemke, R., Wang, Z.H. and Chanabra, B.S. (2006). Tillage, nitrogen and crop residues effects on crop yield, nutrient uptake, soil quality and green house emission. In: Soil Tillage Res. 90(1-2): 171-183.

Oleshko, V.P., Shott, P.R. and Yakovlev, V.V. (1995). A source of supplementary fodder. Kormoproizvodstvo 3: 23.

Swarup, A. (1991). Long-term effect of green manuring (Sesbania aculeata) on soil properties and sustainability of rice and wheat yield on sodic soil. J. Indian Soc. Soil Sci.39: 777-778.

Vasanthi, D. and Kumarasamy, K. 1999. Efficacy of vermicompost to improve soil fertility and rice yield. Journal Indian Society of Soil Sciences, 42(2): 268- 272.

Yadav, R. L. and Sharma, R. K. (1980). Effect of nitrogen levels and harvesting dates on quality characters and yield of four sugarcane genotypes. Indian Journal of Agricultural Sciences 50:581-589.

\section{How to cite this article:}

Khumlo Levish Chongloi. 2021. Soil Nutrient Uptake and Balance as Influenced by Intercropping and Integrated Nutrient Management. Int.J.Curr.Microbiol.App.Sci. 10(02): 1176-1184. doi: https://doi.org/10.20546/ijcmas.2021.1002.138 